\section{Space-based observation of a high-altitude red-coloured glacial lake in Ladakh, Northwest Himalaya, India}

\author{
Pratima Pandey ${ }^{1}$, Prakash Chauhan ${ }^{1, *}$, \\ S. Nawaz Ali $^{2}$ and Mamta Chauhan ${ }^{1}$ \\ ${ }^{1}$ Indian Institute of Remote Sensing, Indian Space Research \\ Organization, Dehradun 248 001, India \\ ${ }^{2}$ Birbal Sahni Institute of Paleosciences, Lucknow 226007 , India
}

The present study reports the existence of a unique and unusual feature of the Zanskar valley, Ladakh, India - a proglacial 'red/brown-coloured lake' observed from space-based remote sensing data. The lake has not changed in colour and size over the years. Here we report observations from 2004 onwards till recently. The local geology plays an important role, and iron-dominated lithology of the region interacts with snow and glacial meltwaters and subsequently deposits $\mathrm{red} / \mathrm{brown}$-coloured suspended silt in this proglacial lake. Spectral analysis of reflectance data from Sentinel-2 images in visible-infrared region of electromagnetic spectrum suggests that the colour of the lake is due to high concentration of suspended solids, having dominant reflectance at $660-700 \mathrm{~nm}$ and thus causing the red/brown colour of the water.

Keywords: Proglacial lake, remote sensing, spacebased observations, suspended solids.

THE Zanskar valley, Ladakh, India lies between the Karakoram Range in the north and the Great Himalayan Range in the south, and offers surreal landscapes (such as glaciers, glacial lakes, saline lakes, permafrost features and dunes) and fascinating geology. Climatologically, the region (Zanskar) lies in the transitional zone of two most important atmospheric circulation systems, viz. the Indian summer monsoon and the mid-latitude westerly winds, and where the earth surface/geomorphic processes are known to sensitively respond to precipitation and temperature changes. Hence the region has preserved evidences of past climate variability that may help in ascertaining climate processes and their regional and global correlations ${ }^{1-4}$. This arid part of the Indian Himalaya is least populated due to harsh and extreme climate, and scanty vegetation. A fair number of studies pertaining to the climate of the region ${ }^{5}$, change in glaciers ${ }^{6}$, glacial lakes ${ }^{7}$ and diverse landforms due to permafrost, glacial activity, etc. ${ }^{8}$ have been carried out in the region. However, owing to the extreme high-altitude environment of the region with lower oxygen levels, higher ultraviolet (UV) radiation and extreme cold weather, most of the remote locations in Ladakh remain unexplored and unknown.

*For correspondence. (e-mail: prakash4140@gmail.com)
The ongoing global warming has resulted in continued glacier melting and the formation and expansion of glacial lakes in the Himalayan region ${ }^{9-11}$. One such glacial lake, which is $\sim 30 \mathrm{~km}$ southwest of Lamayuru - 'moon land of Ladakh', Leh, shows a unique reddish/brownish colour. The glacial lake is located at $34^{\circ} 0.280^{\prime} \mathrm{N}$ and $76^{\circ} 43.295^{\prime} \mathrm{E}$, at an altitude of $\sim 5060 \mathrm{~m}$ amsl (Figure $1)^{12,13}$. The distance of the lake from the nearest road and village Photoskar ( $\sim 200 \mathrm{~m}$ amsl) is $\sim 11 \mathrm{~km}$. This lake is dominantly fed by meltwater from its northeasterlyfacing mother glacier. The morphometry analysis shows that the lake covers an area of $\sim 0.19 \mathrm{~km}^{2}$, perimeter of $\sim 1.19 \mathrm{~km}$, length of $\sim 700 \mathrm{~m}$ and width of $\sim 300 \mathrm{~m}$. The orientation of the lake is northeast and slope between the mother glacier and the red lake is about $20^{\circ}$. The shape index reveals a near circular shape of the lake (shape index 0.75). Analysis of the time-series images of the red/brown lake (red lake henceforth) indicates that the size and colour of the lake have not changed over the years (Figure 2). The water body of the lake remains frozen during winter season spanning from November to April.

According to various reports available in the public domain, there are only 29 pink lakes in the world ${ }^{14}$. Lake Hillier in Western Australia is one of the famous pink lakes and the colouration is considered to be due to the algae Dunaliella salina, which grows well in salty environment only ${ }^{15}$. Recently, the water of Lonar Lake in Maharashtra, India has turned pink due to large presence of the salt-loving Haloarchaea microbes ${ }^{16}$. However, the pink colour of Dusty Rose Lake in British Columbia, Canada, which is a glacial lake, is due to its surrounding rocks and not due to algae ${ }^{17}$. Similarly, the Blood Falls of Taylor Glacier, Antarctica, contains a diverse microbial community that is metabolically active, and influences weathering and gives a reddish colour to the meltwater ${ }^{18-20}$. Due to the discovery of such unique environments, the subglacial environments have become important for scientific research ${ }^{21-23}$; however, such research is largely lacking in the Himalayan region.

The red lake identified in the Ladakh Himalaya is a high-altitude lake located at $\sim 5060 \mathrm{~m}$ amsl, average surface temperature of which varies from $\sim-16^{\circ} \mathrm{C}$ during winter to $\sim 6^{\circ} \mathrm{C}$ during summer. The study area is located on the transition of Zanskar Tethyan Zone which formed during the progress of India-Asia collision that has resulted in the closure of the Neo-Tethys Ocean at $\sim 55 \mathrm{Ma}$ (refs 13, 24-27) and Spontang ophiolite complex (SOC) which is an ophiolite klippe that overlies the volcanosedimentary mélange $\mathrm{e}^{25,27,28}$. The meta-sedimentary rocks of the Zanskar Range contain 'ferruginous formation' rich in ironstone ${ }^{24}$. The NE-facing glacier and catchment area feeding the red lake are located on these rock formations of Zanskar. Therefore, we propose that the persistent red and brown colour of the meltwater is likely due to the soluble iron complexes derived from weathering of 


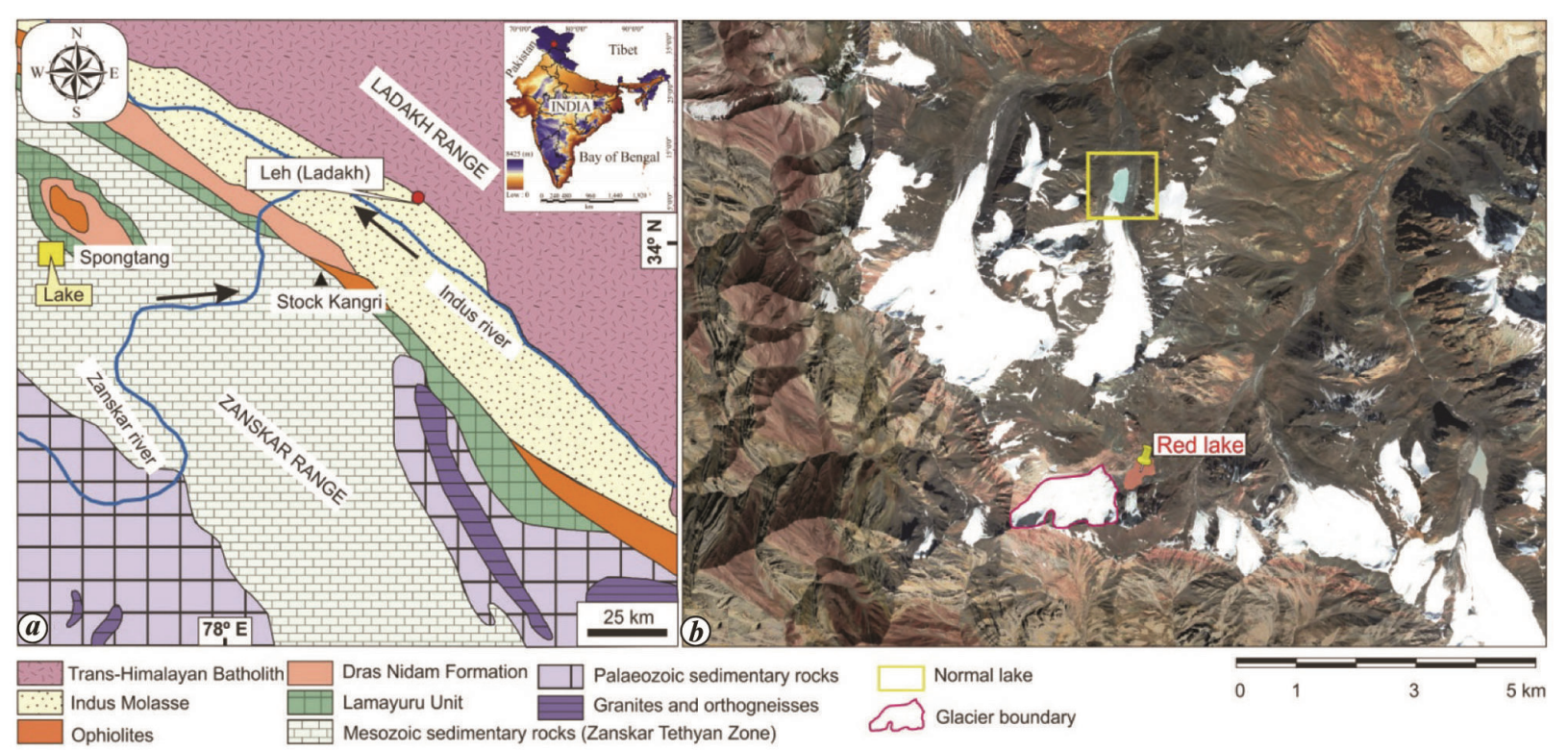

Figure 1. $\boldsymbol{a}$, Geological map of the red lake area and its surroundings (modified after Thakur ${ }^{12}$ and Schlup et al. ${ }^{13}$ ). Location of the lake is shown as a yellow square. $\boldsymbol{b}$, Google Earth image dated 17 October 2017, showing the red lake and adjoining normal blue-coloured proglacial lake.

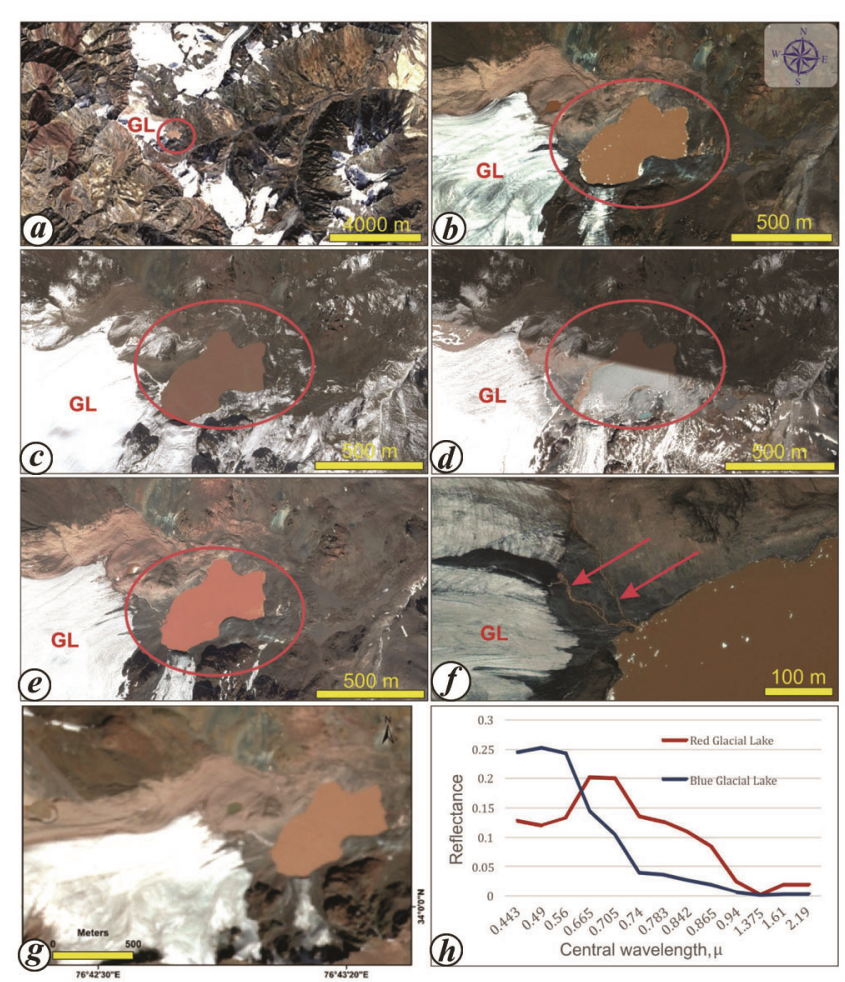

Figure 2. Time series images obtained from Google Earth Pro showing the mother glacier (GL) and the colouration of the red lake in $(\boldsymbol{a})$ 2000; (b) 2004; (c) 2013; (d) 2014; (e) 2017; ( f ) Close-up of the 2004 images showing the colour (red arrow) of melt water; $(g)$ Natura colour composite (bands 4, 3,2) of Sentinel 2A dated 4 October 2020 showing the red lake; (h) Spectral response curves of the red glacial lake and the nearby blue glacial lake (shown in Figure $1 \mathrm{~b}$ ) obtained from Sentinel 2A dated 30 August 2020.

iron-rich bedrock. Besides, the SOC comprises of mantleperidotites (lherzolites, harzburgites), dunites, gabbro, diorites and plagiogranites in form of numerous boulders (peridotites), dykes (gabbroic), lenses (dunites) interbedded with volcanoclastic deposits ${ }^{29}$. The characteristic mineralogy of these mafic and ultramafic rocks being dominated by olivine and pyroxenes makes them metastable at surficial conditions, especially in the presence of aqueous fluids. Dissolution of primary olivine and pyroxene is accompanied by precipitation of secondary phases in the form of clay minerals, carbonates and iron oxide and hydroxides. Therefore, the red coloration of the lake may be imparted by the formation of hematite and goethite as a result of near-surface aqueous weathering of iron-bearing mafic and ultramafic rocks. It has been reported that the glacier meltwater in the Himalayan regions is rich in chloride $\left(\mathrm{Cl}^{-}\right)$, bicarbonate $\left(\mathrm{HCO}_{3}^{-}\right)$and sulphate $\left(\mathrm{SO}_{4}^{2-}\right)$ ions ${ }^{30}$ which can form stable soluble complexes with $\mathrm{Fe}^{2+}$ at $\mathrm{pH}$ ranging between $\sim 7.0$ and 8.0 (ref. 31). The release of $\mathrm{Fe}^{2+}$ in the meltwater could have been enhanced by interaction of $\mathrm{Cl}^{-}$-rich meltwater with frozen iron oxide-rich fluids in the sub aerial sections of the catchment area. Besides, microbially induced weathering of sub-glacial bedrock minerals could be another viable source of $\mathrm{Fe}^{2+}$. However, differences in water residence times, water-rock ratios, refreezing at the waterice interface, basal geologic conditions, and biological processes can produce different water chemistries ${ }^{32}$, and hence need further studies.

Due to the above described geochemistry, the lake is expected to have high concentration of suspended solids. A spectral analysis of the red glacial lake water compared to a typical blue glacial lake water (Figure $2 h$ ) using Sentinel-2 images dated 15, 25 and 30 August 2020 revealed marked difference in the spectral response of water of the red lake. The peak reflectance of the spectrum of the red lake occur at $660-700 \mathrm{~nm}(0.66-0.7 \mu \mathrm{m})$ 


\section{RESEARCH COMMUNICATIONS}

wavelength range, compared to the peak of the blue water lake at $0.49-0.55 \mu \mathrm{m}$. This marked difference gives the lake its unique red/brown colour.

The colour of this high-altitude glacial lake might be affected due to snow/ice meltwater interaction with local lithology. It will be worthwhile to study this phenomenon and geochemical processes by conducting extensive field campaigns during the next summer season in this region. Therefore, we propose a systematic study of this lake that will provide important insights in understanding the ecology of such sub-glacial environments along with the geochemistry and glacier dynamics in the Himalaya.

1. Pisharoty, P. and Desai, B. N., Western disturbances and Indian weather. Indian J. Meteorol. Geophys., 1956, 7, 333-338.

2. Rao, Y. P. and Srinivasan, V., Discussion of typical synoptic weather situations: winter-western disturbances and associated features. Fore-casting Manual No. 3.1.1, Indian Meteorological Department, New Delhi, 1969.

3. Benn, D. I. and Owen, L. A., The role of the Indian summer monsoon and the mid-latitude westerlies in Himalayan glaciation: review and speculative discussion. J. Geol. Soc. India, 1998, 155(2), 353-363.

4. Dimri, A. P., Niyogi, D., Barros, A. P., Ridley, J., Mohanty, U. C., Yasunari, T. and Sikka, D. R., Western disturbances: a review. Rev. Geophys., 2015, 53(2), 225-246.

5. Thayyen, R. J., Hydrology of the cold-arid Himalaya. In Himalayan Weather and Climate and their Impact on the Environment (ed. Dimri, A. P. et al.), Springer Nature, 2020, https://doi.org/ 10.1007/978-3-030-29684-1_20.

6. Schmidt, S. and Nüsser, M., Changes of high altitude glaciers in the Trans-Himalaya of Ladakh over the past five decades (19692016). Geosciences, 2017, 7(2), 27; https://doi.org/10.3390/ geosciences 7020027.

7. Schmidt, S., Nüsser, M., Baghel, R. and Dame, J., Cryosphere hazards in Ladakh: the 2014 Gya glacial lake outburst flood and its implications for risk assessment. Nat. Hazards, 2020; https://doi.org/10.1007/s11069-020-04262-8.

8. Pandey, S. et al., Ladakh: diverse, high-altitude extreme environments for off-earth analogue and astrobiology research. Int. J. Astrobiol., 2019, 1-21.

9. Shukla, A., Garg, P. K. and Srivastava, S., Evolution of glacial and high-altitude lakes in the Sikkim, Eastern Himalaya over the past four decades (1975-2017). Front. Environ. Sci., 2018, 6; doi.org/10.3389/fenvs.2018.00081.

10. Khadka, N., Zhang, G. and Thakuri, S., Glacial lakes in the Nepal Himalaya: inventory and decadal dynamics (1977-2017). Remote Sensing, 2018, 10(12), 1-19.

11. Kumar, R. et al., Lake inventory and evolution of glacial lakes in the Nubra-Shyok basin of Karakoram Range. Earth Syst. Environ., 2019; doi.org/10.1007/s41748-019-00129-6.

12. Thakur, V. C., Regional framework and geodynamic evolution of the Indus-Tsangpo Suture Zone in Ladakh Himalaya. Trans. $R$. Soc. Edinburgh, Earth Sci., 1981, 72, 89-97.

13. Schlup, M., Carter, A., Cosca, M. and Steck, A., Exhumation history of eastern Ladakh revealed by ${ }^{40} \mathrm{Ar} /{ }^{39} \mathrm{Ar}$ and fission-track ages: the Indus River-Tso Morari transect, NW Himalayas. J. Geol. Soc. India, 2003, 160, 385-399.

14. https://destinedto.com/2018/12/31/29-pink-lakes-are-discoveredaround-the-world-till-now/ (accessed on 27 October 2020).

15. McGrath, K., The eXtreme Microbiome Project (XMP) presents: The mystery of the pink lake, 2016; https://vimeo.com/168673450 (accessed on 27 October 2020)
16. https://timesofindia.indiatimes.com/travel/travel-news/scientistsreveal-why-lonar-lake-in-maharashtra-turned-pink-in-color/as77120314.cms\#: :text=The\%20color\%20of\%20Lonar\%20lake,and $\%$ 20exists\%20in\%20saline\%20water (accessed on 27 October 2020).

17. https://looseteamusictheatre.com/shows/dustyroselake/ (accessed on 27 October 2020).

18. Black, R. F., Jackson, M. L. and Berg, T. E., Saline discharge from Taylor Glacier, Victoria Land, Antarctica. J. Geol., 1865, 74, $175-181$.

19. Mikucki, J. A., Foreman, C. M., Sattler, B., Lyons, W. B. and Priscu, J. C., Geomicrobiology of Blood Falls: an iron-rich saline discharge at the terminus of the Taylor Glacier, Antarctica. Aquat. Geochem., 2004, 10, 199-220.

20. Mikucki, J. A. et al., A contemporary microbially maintained subglacial ferrous 'ocean'. Science, 2009, 324, 397-400.

21. Laybourn-Parry, J. and Wadham, J., Antarctic Lakes, Oxford University Press, Oxford, UK, 2014.

22. Siegert, M. J., Ross, N. and Le Brocq, A. M., Recent advances in understanding Antarctic subglacial lakes and hydrology. Philos. Trans. R. Soc. A, 2016, 374(2059), 20140306.

23. Lyons, W. B. et al., The geochemistry of englacial brine from Taylor Glacier, Antarctica. J. Geophys. Res.: Biogeosci., 2019, 124(3), 633-648.

24. Gaetani, M., Casnedi, R., Fois, E., Garzanti, E., Jadoul, F., Nicora, A. and Tintori, A., Stratigraphy of the Tethys Himalaya in Zanskar, Ladakh (initial report). Riv. Ital. Paleontol. Strat., 1986, 91(4), 443-478.

25. Searle, M., Structural evolution and sequence of thrusting in the High Himalayan, Tibetan-Tethys and Indus suture zones of Zanskar and Ladakh, Western Himalaya. J. Struct. Geol., 1986, 8(8), 923-936.

26. Steck, A., Epard, J., Vannay, J., Hunziker, J., Girard, M., Morard, A. and Robyr, M., Geological transect across the Tso Morari and Spiti areas - the nappe structures of the Tethys Himalayas. Eclogae Geol. Helv., 1998, 91, 103-121.

27. Mathur, N. S., Juyal, K. P. and Kumar, K., Larger foraminiferal biostratigraphy of lower Paleogene successions of Zanskar Tethyan and Indus-Tsangpo Suture Zones, Ladakh, India in the light of additional data. Himalayan Geol., 2009, 30(1), 45-68.

28. Buckman, S. et al., The Spongtang Massif in Ladakh, NW Himalaya: an early Cretaceous record of spontaneous, intra-oceanic subduction initiation in the Neotethys. Gondwana Res., 2018, 63, 226-249.

29. Reuber, I., Geometry of accretion and oceanic thrusting of the Spontang ophiolite. Ladakh Himalaya. Nature, 1986, 321, 592596.

30. Ahmad, S. and Hasnain, S. I., Meltwater characteristics of Garhwal Himalayan glacier. J. Geol. Soc. India, 2000, 56, 431-439.

31. Didukh, S., Losev, V., Borodina, E., Maksimov, N., Trofimchuk, A. and Zaporogets, O., Separation and determination of Fe(III) and $\mathrm{Fe}(\mathrm{II})$ in natural and waste waters using silica gel sequentially modified with polyhexamethylene guanidine and tiron. J. Anal. Methods Chem., 2017.

32. Wadham, J. L. et al., Biogeochemical weathering under ice: size matters. Global Biogeochem. Cycles, 2010, 24(3), GB3025(1-11).

ACKNOWLEDGEMENTS. P.P. thanks Dr Shovanlal Chattoraj and Supriya Sharma (Indian Institute of Remote Sensing, ISRO, Dehradun) for help and support. S.N.A. thanks the Director, Birbal Sahni Institute of Palaeosciences, Lucknow for encouragement and support.

Received and accepted 19 November 2020

doi: $10.18520 / \mathrm{cs} / \mathrm{v} 120 / \mathrm{i} 2 / 429-431$ 